NBER WORKING PAPER SERIES

\title{
PITFALLS OF A STATE-DOMINATED FINANCIAL SYSTEM: THE CASE OF CHINA
}

\author{
Genevieve Boyreau-Debray \\ Shang-Jin Wei
}

Working Paper 11214

http://www.nber.org/papers/w11214

\author{
NATIONAL BUREAU OF ECONOMIC RESEARCH \\ 1050 Massachusetts Avenue \\ Cambridge, MA 02138 \\ March 2005
}

The authors would like to thank Ray Brooks, Chun Chang, Martin Feldstein, Simon Johnson, Nick Lardy, Huayong Ge, Albert Keidel, Raghu Rajan, Eswar Prasad, Gang Yi, and seminar and conference participants at the National Bureau of Economic Research, the IMF, and the Hong Kong University for very useful comments, and Heather Milkiewicz for research assistance. The views expressed are the authors' own, and do not represent those of the World Bank, the IMF, or their respective policies. The views expressed herein are those of the author(s) and do not necessarily reflect the views of the National Bureau of Economic Research.

(C) 2005 by Genevieve Boyreau-Debray and Shang-Jin Wei. All rights reserved. Short sections of text, not to exceed two paragraphs, may be quoted without explicit permission provided that full credit, including () notice, is given to the source. 
Pitfalls of State-Dominated Financial System: The Case of China

Genevieve Boyreau-Debray and Shang-Jin Wei

NBER Working Paper No. 11214

March 2005

JEL No. G1, F3

\begin{abstract}
State-owned financial institutions have been proposed as a way to address market failure, but the recent literature has also highlighted their pathological problems. This paper studies the case of China for pitfalls of a state-dominated financial system, including possible segmentation of the internal capital market due to local government interference and mis-allocation of capital. Even without formal legal prohibition to capital movement across regions, we find that capital mobility within China is low. Furthermore, to the extent some capital moves around the country, the government (as opposed to the private sector) tends to allocate capital systematically away from more productive regions toward less productive ones. In this context, a smaller role of the government in the financial sector might increase economic efficiency and the rate of economic growth.
\end{abstract}

Genevieve Boyreau-Debray

East Asia Pacific Region

Poverty Reduction and Economic Management Unit

The World Bank

Washington, DC 20433

gboyreaudebray@worldbank.org

Shang-Jin Wei

Research Department

International Monetary Fund

700 19th Street NW

Washington, DC 20431

and NBER

swei@imf.org 


\section{INTRODUCTION}

Government ownership of banks is common across countries (La Porta, et al, 2002). In some cases, the state dominates the entire financial system. The efficiency of a state-dominated financial system is controversial in theory. On the one hand, market failure in the financial market such as a tendency towards natural monopoly due to scale economies or externality associated with a banking panic has inspired scholars to think of positive roles for a government in a financial system (e.g., Stglitz and Weiss, 1981, and Greenwald and Stiglitz, 1986). On the other hand, a big role of the government in finance could have its share of problems if one recognizes that state ownership may be used by politicians to pursue private objectives. Shleifer (1998) and Shleifer and Vishny (1998) provided a sweeping overview of potential problems associated with state ownership in general ${ }^{2}$.

In this context, China has generated much controversy in the literature. Franklin Allen, Jun Qian and Meijun Qian (forthcoming) argue that the Chinese case proves that an effective financial system does not depend on the standard, Western institutions (either of common law or civil law tradition). In spite of state dominance on the surface, a sufficient amount of alternative, informal financial mechanism has emerged so that the overal financial system functions effectively. In Allen et al's words, "China is an important counterexample to the findings in the law, finance, and growth literature: neither its legal nor financial system is well developed by existing standards, yet it has one of the fastest growing economies." On the other hand, Alwyn Young (2001), argues that the Chinese model of development is not something to be emulated, given the massive distortions in the economy, especially the rising regional protectionism in the goods market.

Given the importance of China in the world economy, and especially the potential implications for the literature on competing financial development models, this paper takes a close look at the working of the Chinese capital market in order to shed lights on how the state-dominated financial system actually works in this case. To our knowledge, a quantitative assessment of the efficiency of the Chinese capital market does not exist in the literature.

The economic takeoff of China over the last quarter of century bears many similarities to the economic takeoffs of Europe and North America in late $19^{\text {th }}$ century. The process is accelerated in the case of China, but features such as a steady decline of agriculture as a share of national output and a

\footnotetext{
${ }^{2}$ Using data on Italian banks, Sapienza (forthcoming) shows that state-owned banks charge lower interest rates than do private banks, and that this difference is largely explained by political patronage.
} 
corresponding rise of the manufacturing sector, and a steady increase in the educational level of the workforce in response to improving premia on education are similar to the Western economic history. However, a striking difference between the two "economic miracles" lies in the organization of the financial systems. While Europe and North America had relied largely on a private-sector-driven financial system during their economic takeoffs (albeit with differential reliance on banks versus stock markets), China has maintained a government-dominated financial system. There are two categories of government domination. First, entry barriers to commercial banking, investment banking and other financial services are tightly controlled so that the concentration of the financial sector in state-owned entities remains extraordinarily high despite twenty-five years of reforms in most other areas of the economy. Second, the central government and especially the local governments at various levels actively interfere with the functioning of the capital market by directing and encouraging some bank loans or stock listings while discouraging or even prohibiting others. Outside the banking sector, capital market is not as well-developed in proportion to the size of the economy. As Allen et al (forthcoming) point out, compared with countries in the LLSV (1997, and 1998) sample, China does not score well in terms of creditor and shareholder rights, or in terms of quality of rule of law generally. Given the record of high economic growth rates in China, one may be tempted to think that the state-dominated financial system has somehow overcomed problems associated with poor creditor/shareholder rights and contributed to the economic take-off. In fact, Allen et al use this observation to emphasize the importance for alternative, informal financial mechanism to emerge to support the economic growth.

Careful studies of the Chinese financial system in the finance literature are extremely rare ${ }^{3}$. This is unfortunate: Beyond the peculiarities of the Chinese institutions, the country's experience holds general lessons for the literature on comparative financial systems. In this paper, we fill this void by systematically examining the working of the Chinese financial system with a focus on the mobility of capital and efficiency of capital allocation. Specifically, we make use of regional data to investigate whether frequent government interventions and state ownship of the financial system show up as significant barriers to the mobility of capital across regions (and whether private capital

\footnotetext{
${ }^{3}$ Other than the Allen et al paper, the main exception is the attention paid to the problem of non-performing loans (e.g., Lardy, 1998) though their causes and consequences have not been subject to much sophisticated analysis. There are papers in other branches of economics that have examined various aspects of the Chinese economy that are somewhat related to this paper, including economic federalism (Qian and Xu, 1993), segmentation of the goods market, and restrictions on labor migration (Young, 2001; Naughton, 2000; Huang and Wei, 2001; and Poncet, 2002).
} 
mobility is large enough to offset any lack of mobility of the official finance). We also examine, to the extent some capital does move around, whether the mobility is consistent with efficiency.

To preview the central findings of the paper, we will document that the capital mobility is low within China, and that the government (as opposed to the private sector) tends to allocate capital systematically away from more productive regions toward less productive ones. This peculiar capital allocation rule is mainly to favor inefficient state-owned firms. Therefore, the state-dominated financial system severely retards the efficient allocation of capital. The private capital does not seem to be large enough to undo the inefficiency associated with the government-dictated finance. In this sense, a smaller role of the government in the financial system may very well improve the efficiency and raise the growth rate of the economy.

The rest of the paper is organized in the following way. To put some institutional texture to the subsequent statistical analyses, section II briefly describes the channels for capital mobility within China. Section III conducts a series of tests on financial interpretation from the invested side. Section IV studies the degree of consumption risk sharing. Section V examines how capital allocation relates to marginal product of capital. Section VI offers concluding thoughts. An appendix describes the data.

\section{INSTITUTIONAL BACKGROUND ON CAPITAL MOBILITY IN CHINA}

There are three main channels to move capital from one region to another within a country: (a) cross-regional investment by firms and government, (b) cross-regional lending by the banking system, and (c) raising capital by firms from sources outside the region (e.g. using the bond and stock markets).

\section{a) Cross-Regional Investment by Firms and Government}

How easy is it to for a firm in one region in China to invest in another region? At a first glance, nationwide regulations and tax system are fairly neutral for a firm choosing to invest elsewhere. Indeed, there is no formal or legal prohibitions from capital to move from one region to another. However, the government dominates the economy in a variety of ways. And the financial system is by and large state owned. There are important regional barriers and special fiscal incentives that distort the national capital market. Local governments are reluctant to see capital flowing out of their jurisdiction because it may imply a revenue loss to them. Furthermore, local governments may also fear losing good performing enterprises with associated job losses. As a result, most mergers and 
acquisitions tend to be localized (e.g., within a province) rather than across regions because of resistance at various levels of the bureaucracy.

By contrast, the central government has been active for redistributing resources from one region to another. Its importance, however, has declined over time: The share of investment financed by the state declined from 28 percent in 1981 to 7 percent in $2001 .^{4}$ Overall, it is an open question whether within-China capital mobility has increased over time.

\section{b) Cross-Regional Lending by the Banking Sector}

The banking system comprises the central bank; four large state-owned commercial banks, three policy banks, ten national joint-stock commercial banks, about 90 regional commercial banks, and about 3,000 urban and 42,000 rural credit cooperatives. There are also branches or representative offices of foreign banks with limited activities. The four state-owned commercial banks dominate the market. As of late 2001, they accounted for 63 percent of loans outstanding and 62 percent of deposits. With 103,000 branches among them, they are the only financial institutions that cover virtually all locations in China.

Within the banking system, there are three main channels for transferring financial resources from one region to another: fund reallocation among regional branches of national banks (within-bank transfer); the interbank market (between-bank transfer) ${ }^{5}$ and central bank lending to the regions.

Up to the early 1990s, the government had been using a system of credit ceilings for controlling the money supply. Under this system, within and between-bank transfers were limited. Quotas were imposed on bank lending for each bank and in turn broken down by region. Interbank lending and borrowing have however contributed to capital mobility to a certain extent. Some observations suggest that within and between-bank transfers are likely to have increased as bank were given more autonomy in the 1990s.

\footnotetext{
${ }^{4}$ More recently, the government has initiated a new policy focusing on the development of the western region as an attempt to re-equilibrate China's regional development which previously had been overwhelmingly favorable to the coastal region. This new policy launched in 2000 has two main components: the development of infrastructure with the central government investment in the region and the provision of tax exemption and other fiscal incentives to the western provinces.

${ }^{5}$ Park and Sehrt, 2001.
} 
Central bank lending has been an important policy instrument for allocating resources over the credit plan period. The central bank engaged in a massive redistribution of bank deposits to support the credit plan and policy lending objectives. The vast majority of PBC relending was channeled through PBC local branches. The reforms of the recent years, however, have likely reduced the role of central bank in the spatial allocation of capital.

\section{c) Cross-Regional Raising of Capital Using the Stock and Bond Markets}

Although banks dominate the financial sector, there are recent signs of a shift towards other forms of financing. The share of firm financing accounted for by equity issuance increased from 1 percent in the early 1990s to 14 percent in 2000. Households invested 20 percent of their financial assets in the form of securities (14 percent in stock, 6 percent in bonds), compared to 14 percent only 3 years earlier. These changes, in principle, are likely to accompany greater interregional capital mobility over time. Unfortunately there is no official or systematic information on the geographic distribution of shareholders and bondholders. Some anecdotal evidence appears to suggest that they are very concentrated in the relatively well-off coastal regions. This would suggest that the role of stock and bonk markets in promoting capital mobility is still very limited.

To sum up, some observations may suggest that the Chinese financial system is compatible with increasing capital mobility over time and efficient allocation of capital across regions while a number of other factors would cast doubt on this proposition. To understand the working of this system, it is important to utilize formal statistical tools to quantify the extent of capital mobility and the level of allocative efficiency.

\section{ARE LOCAL INVESTMENTS CONSTRAINED by LOCAL SAVINGS ?}

We now turn to evidence on the mobility of capital in China. We tackle the problem from three complementary angles. First, we investigate whether the financial system succeeds in channeling funds to locations where the demand is the greatest so that local investments are not constrained by the size of local savings. Second, we turn from a firm's to a household's angle, and check whether household's ability to smooth consumption has been enhanced by the financial system. Third, we construct location-specific measure of marginal product of capital and examine if the financial system helps to channel capital to go to the most productive regions.

In search for appropriate statistical tools for these questions, we have identified a number of tests that are standard in the international finance literature and whose properties are well 
documented. We will discuss these tests sequentially, starting with a test in this section on whether invesment is constrained by local savings.

\section{a) Basic Idea}

To motivate the test on whether local savings constrain local investment, we start with two hypothetical extreme cases. With zero capital mobility across regions, local savings can only be invested locally, and all local investment has to be financed by local savings. In this case, local investments and local savings should be perfectly correlated. In the other extreme, with perfect capital mobility, savings from any particular locale can go anywhere in search of the best return-risk tradeoff. In other words, local savings respond to global opportunities for investment; local investment is financed by a national or international pool of capital. There need not be any exact relationship between local saving and local investment. While this does not necessarily imply a correlation of zero, the correlation should be substantially below one. This is the fundamental idea of Feldstein and Horioka (1980) who proposed to use the saving-investment correlation as a measure of (lack of) capital market integration.

The Feldstein-Horioka (FH) test was initially proposed as a test of world capital market integration, i.e. as a measure of the degree of capital mobility across countries. In that context, the literature suggests that it does not give conclusive evidence on capital mobility because a low savinginvestment correlation can be consistent with various alternatives other than a low degree of capital market integration across countries. These alternatives include the presence of a risk premium associated with currency devaluation, and governments' effort to target the level of current account balance by manipulating the exchange rate. However, within a country, the FH test turns out to be a reasonable indicator of the degree of capital market integration across different regions. The main reason is that the alternative interpretations mentioned above are not operative within a country. Specifically if different parts of a country share a common currency, there is no currency devaluation to speak of. Regional governments are also less likely to have a current account target at the regional level. ${ }^{6}$ In other words, the FH test is better suited for testing capital mobility within a country than across countries.

Before we apply the FH test to China, it would be useful to see if the FH test actually produces low investment-saving correlations when applied to countries known to have a degree of

\footnotetext{
${ }^{6}$ Note that local protection in the goods market and current account target are not the same thing.
} 
internal financial integration. The obvious would be developed countries such as the United States and Japan. Luckily, there is a body of papers that have studied saving-investment correlations within individual developed countries including Sinn (1992) for the United States, Thomas (1993) for the United Kingdom, Canada, and Germany, and Bayoumi and Rose (1993), Yamori (1995), and Deckle (1996) for Japan. All of these countries are known to have an integrated capital market internally. Each of the papers has found non-significant or sometimes negative saving-investment correlations across the regions. Taken together, this literature provides a justification for using the FH test to examine capital market integration within China.

In this section, we first present simple (unconditional) correlations between saving and investment across Chinese provinces and compare them with the corresponding figures from countries with known integrated internal market. We then compute a series of conditional correlations, following a procedure used by Iwamoto and van Wincoop (2000), that control for a number of factors other than capital market integration that can affect the saving-investment correlation. Because China's capital market is largely dominated by the banking system, we also perform the same tests using bank deposit and loan data: to which extent the local banking system has to rely on local deposits for new loans.

\section{b) Unconditional FH Test}

We make use of a panel data set on Chinese provinces (or province-level entities) during 1952-2001 (28 provinces for 1978-2001 and 24 for 1952-1977). ${ }^{7}$ The database comes from a vender called A11 China Marketing Research, and consists of provincial GDPs desegregated into household and government consumptions, gross capital formation, change in inventory and net exports.

Provincial saving is defined as regional GDP minus private and government consumptions. Provincial investment is defined as the change in gross capital stock of both the private and public sectors. Both saving and investment are expressed as a ratio of provincial GDP. ${ }^{8}$

Table 1 reports the correlations of investment and saving rates in the Chinese provinces averaged over the pre-reform period (1952-1977), the reform period (1978-2001) and two sub-

\footnotetext{
${ }^{7}$ The provinces of Jianxi, Guangdong and Hainan, Sichuan and Chongqing and Ningxia have been excluded for the pre-reform period because of lack of data.

${ }^{8}$ We have tested for the order of integration of the series using panel unit-root tests (Im, Pesaran, and Shin, 1997). Both investment and saving rates (in percent of GDP) are stationary.
} 
periods within the reform period (1978-1989 and 1990-2001). ${ }^{9}$ For comparison, Table 1 also reports the corresponding figures for the national economies of OECD countries. ${ }^{10}$

The averaged correlation between local investments and savings is approximately 0.53 both before and during the reform period (1952-77 and 1978-2001, respectively). By comparison, correlations between investment and saving rates within member countries of the OECD such as Japan or the United States where a high degree of capital mobility is insignificantly different from zero or even negative. On the opposite extreme, correlations between investment and saving rates across OECD member countries are 0.71 between 1960 and 1977 and 0.45 between 1978 and 2001, as reported at the bottom of Table 1. Hence, the intra-national correlation levels found in China are much closer to a between-country level than to a within-country level relative to the evidence based on OECD countries. These comparisons suggest the presence of barriers to capital mobility across the Chinese regions.

We next examine the evolution of the saving-investment correlation over time. The results are reported in columns 3 and 6 of Table 1 . These correlations do not vary much before and over the reform period, as shown by the insignificance of the difference. By contrast, the correlation sharply increases from 0.30 in the 1980 s to 0.60 in the 1990 s (column 6, Table 1). This result is somewhat surprising if we believe that the capital market should have become incrementally more integrated over time along with the progresses in market reforms and opening-up of the economy.

As already mentioned, simple correlations based on raw data only provide a preliminary measure of financial integration, as factors other than market integration can affect the correlation. In the following sub-section, we apply a conditional FH test to control for these factors.

\section{c) Conditional FH Test}

The conditional FH test that we use follows the strategy proposed by Iwamoto and van Wincoop (2000). The idea can be explained intuitively. If financial markets are integrated, investment depends on factors that determine the global and national supplies of funds, those that determine the productivity of capital, and a set of region-specific factors. Similarly, saving in the same country also

\footnotetext{
${ }^{9} \mathrm{We}$ also investigate the presence of structural breaks in the series over the 1990s but do not find any.

${ }^{10}$ The data on investment and saving for OECD member countries come from the United Nations National Accounts Statistics and are available from 1960 onwards.
} 
depends on the same set of global and region-specific factors. The global and national factors can be condensed and labeled as g. Those region-specific factors which affect investment and saving can be organized as a set of uncorrelated vectors $\mathrm{v}, \mathrm{w}$, and $\mathrm{z}$, whereby $\mathrm{v}$ and $\mathrm{w}$ affect investment, and $\mathrm{v}$ and $\mathrm{z}$ affect saving. In other words, $\mathrm{v}$ is a vector of region-specific factors that affect both investment and saving. w (z) is a vector of factors that affect investment (saving) independently. Investment and saving can be expressed respectively as the following functions: $\mathrm{I}=\mathrm{I}(\mathrm{g}, \mathrm{v}, \mathrm{w})$ and $\mathrm{S}=\mathrm{S}(\mathrm{g}, \mathrm{v}, \mathrm{z})$. By construction, if researchers do not control for the effects of $g$ and $v$, then local savings and local investments would be correlated even in the case of a fully integrated financial market.

Iwamoto and van Wincoop implement a method based on this framework to the Japanese prefectures and find that the correlation between local investment and savings becomes zero once the global/national, and regional factors are controlled for. As a result, the authors conclude that the degree of financial integration across Japanese regions is high. We apply their method to the Chinese provinces. First, we control for national shocks by subtracting national saving and investment rates from the province's saving and investment rates:

$$
\begin{aligned}
& \mathrm{S}_{\mathrm{it}} *=\mathrm{S}_{\mathrm{it}}-\mathrm{S}_{\mathrm{it}} \\
& \mathrm{I}_{\mathrm{it}}{ }^{*}=\mathrm{I}_{\mathrm{it}}-\mathrm{I}_{-\mathrm{it}}
\end{aligned}
$$

where $S_{i t}$ and $I_{i t}$ are, respectively, the saving and investment rates in province $\mathrm{i}, \mathrm{S}_{\text {-it }}$ is the national saving rate outside province $i$, and $I_{-i t}$ is the national investment rate outside province $i^{11}$.

Second, we control for region-specific shocks for by regressing saving and investment rates for each province separately on region-specific determinants that can affect saving and investment comovements:

$$
\begin{aligned}
& \mathrm{S}_{\mathrm{it}}{ }^{*}=\alpha_{\mathrm{i}}+\alpha_{\mathrm{y}} \mathrm{y}_{\mathrm{it}}+\alpha_{\mathrm{F}} \mathrm{F}_{\mathrm{it}}+\mathrm{e}^{\mathrm{S}}{ }_{\mathrm{it}} \\
& \mathrm{I}_{\mathrm{it}}{ }^{*}=\beta_{\mathrm{i}}+\beta_{\mathrm{y}} \mathrm{y}_{\mathrm{it}}+\beta_{\mathrm{F}} \mathrm{F}_{\mathrm{it}}+\mathrm{e}^{\mathrm{I}}{ }_{\mathrm{it}}
\end{aligned}
$$

where y measures the stage of local business cycles and F measures regional fiscal policies. The provincial series of business cycles, $y$, are generated by applying a Hodrick and Prescott (HP) filter to

\footnotetext{
${ }^{11}$ Some of the provinces constitute a non-trivial fraction of national saving and investment. We therefore use rest of the country instead of national aggregates in order to avoid distorting the correlations upwards.
} 
the local GDP series. ${ }^{12}$ The fiscal variable, F, is the ratio of local government consumption to local GDP. The residuals $\mathrm{e}^{\mathrm{S}}{ }_{\text {it }}$ and $\mathrm{e}^{\mathrm{I}}{ }_{\mathrm{it}}$ from equations (2a) and (2b), respectively, are then used to compute the new correlation between saving and investment.

Table 2 reports the results. After controlling for national shocks, the average correlation between investment and saving drops to 0.19 over the pre-reform period and to 0.34 over the reform period (row 2, Table 2). When region-specific factors are also controlled, the correlation decreases further to 0.14 and 0.21 over the two time periods, respectively (row 3, Table 2).

However, the increase in the correlation from the 1980s to the 1990s continues to be true even after common national shocks and region-specific (business cycles and fiscal) shocks to local saving and investment are controlled for. As reported Table 2, the correlation rose from 0.04 in the 1980s (Column 4, Row 3) to 0.43 in the 1990s (Column 5, Row 3). So the puzzle remains: there appears to be a deterioration in the capital market segmentation in recent years.

To control for possible simultaneity bias of the regressors, we introduce the one-year lagged values of the region-specific variables and report the results in row 4 of Table 2. This produces very similar results. Finally, for comparison, columns 7 and 8 report the results for within Japan and across the OECD countries. Within Japan, the correlation is not different from zero once national and regional factors are held constant (Column 7, Row 3). By contrast, the correlation across OECD economies is 0.28 (Column 8 , Row 3).

Finally, we investigate the marginal impact of local savings on local investment, i.e., to which extent one extra unit of local saving contributes to finance local investment. To do so, we regress provincial investment rates on local savings rates. The results are similar to the previous ones using investment-saving correlations (not reported to save space). The coefficient of local saving is positive and statistically significant even when national and regional factors are controlled for. There is an increase in the slope coefficient over the 1990s. Therefore, there is no evidence of an improvement in the degree of capital market integration.

\section{d) Capital Mobility Within the Banking Sector}

As China's financial sector is dominated by banks, it may be informative to check directly whether local bank lending is constrained by local deposits. Table 3 reports the statistical results. The

\footnotetext{
${ }^{12}$ We use HP(100) filtered $\log ($ province GDP) minus HP(100) filtered $\log ($ national GDP).
} 
unconditional correlation is of 0.66 over the $1980 \mathrm{~s}$ and 0.5 over the $1990 \mathrm{~s}$, a level similar to the correlations across OECD member countries (0.63 and 0.62, respectively, over the 1980s and the 1990s). When we control for the national trend, the average correlation within China drops to 0.30 over the 1980s but then increases slightly over the 1990s. This suggests that the importance of the national component decreased over the 1980s which was reversed over the 1990s. Indeed, the reforms implemented over the 1990s granting the banks more autonomy have at the same time decreased the importance of central planning. For comparison, the global component for OECD member countries has little impact on the correlation.

Finally, when national and regional factors are both controlled for, the correlation between deposits and loans increases over time, from 0.44 during 1978-89 to 0.58 during 1990-2001 (Row 3, Columns 1 and 2 of Table 3). The increment is statistically significant (Column 3, Row 3), suggesting a possible deterioration in capital mobility within the banking sector over the 1990s.

Overall, the finding of a positive and significant correlation after controlling for the national factors and region-specific shocks suggests that there are still significant barriers to intra-national capital mobility in China. Hence, the pattern for China is closer to that of international capital movements as opposed to intranational capital mobility observed for a country such as Japan with no internal barriers. We have not found evidence of an improvement in capital mobility during 19782001. If anything, there appears to be a decline in capital mobility in the $1990 \mathrm{~s}^{13}$.

\section{IS THERE EFFECTIVE RISK SHARING IN CONSUMPTION?}

In this section, we turn to examining the consumption side of financial integration (as opposed to the investment side in the last section), namely, the extent to which the internal capital market allows sufficient risk-sharing in consumption across different regions.

\section{a) Basic Idea}

In a world with a complete asset market and perfect capital mobility, individuals can, by pooling their risks, insure against uncertainty in their incomes. Household consumption should move one for one with aggregate consumption absent of idiosyncratic fluctuations of preferences.

\footnotetext{
${ }^{13}$ While the finding of a deteriorating capital mobility appears surprising, it is consistent with the evidence of inefficient credit allocation (Cull and Xu, 2000; and Park and Sehrt 2001) and of increasing dispersion of the marginal rates of return to capital (Tan and Zhang, 2003).
} 
Furthermore, changes in consumption across households should not be perfectly correlated with changes in household resources (Obstfeld, 1994, and references therein).

Based on this idea, one can construct another measure of capital market integration. ${ }^{14}$ Given that assumptions of perfect capital mobility and market completeness are at odds with reality, one would not expect to find a perfect coherence in per capita consumption across locations. A more reasonable hypothesis would be to observe, in the presence of increasing capital mobility and financial sophistication, an increasing coherence of consumption fluctuations and a decreasing volatility of consumption relative to that of output. ${ }^{15}$ According to the empirical literature, consumption is more correlated within individual member countries of the OECD, where we know ex ante that the level of financial integration is high, than between them. ${ }^{16}$ One generally finds that intranational risk sharing is much stronger than international risk sharing.

This section is organized as follows: we first present an unconditional test of risk-sharing and then applying a framework by Obstfeld (1994) that allows for an incomplete asset market.

\section{b) Unconditional Test of Consumption Risk Sharing}

Table 4 shows the correlations between the growth of provincial per capita consumption (or output) and that for the rest of the country. ${ }^{17}$ All the data are expressed in real terms using the 1978 prices and in log-difference. We split the sample into two periods: 1952-1977, and 1978-2001. The reform era is further split into two sub-periods: 1978-1989 and 1990-2001. For comparison, we compute similar correlations acorss the OECD countries in similar time periods.

Consumption correlations across the Chinese provinces average 0.62 and 0.54 over the two time periods (Table 4, row 1). By comparison, the corresponding correlations across OECD countries

\footnotetext{
${ }^{14}$ For a survey of the literature on risk sharing see Crucini and Hess (2000).

${ }^{15}$ For instance, Obstfeld (1994) notes that among the G-7 countries over the period 1951 to 1988 there has been a tendency for domestic consumption to become more closely correlated with the world consumption

${ }^{16}$ The intra-national risk-sharing literature has examined Canada (Crucini, 1999, and Bayoumi and McDonald, 1995), Japan (van Wincoop, 1995) and the United States (Atkeson and Bayoumi, 1993; Crucini, 1999; Hess and Shin, 1997; and Asdrubali, Sorensen, and Yosha, 1996.

${ }^{17}$ Some provinces constitute a non-trivial fraction of national output. We therefore use the rest of the country instead of national aggregates (i.e., excluding the province' own contribution to the national average) in order to avoid an upward bias.
} 
were lower ( 0.35 in both periods in Table 4, row 4). This, however, does not necessarily imply that consumption risk sharing is higher across the Chinese regions than across the OECD countries. Indeed, a high level of consumption correlation can reflect a high correlation of local output, coupled with a close association between consumption and output growth rates. As reported in the second row of Table 4, local output growth rates are indeed more highly correlated in China. The correlation coefficients equal to 0.80 over the pre-reform period and 0.65 over the reform period, which are higher than those for OECD member countries (row 5, Table 4).

We thus need to express consumption correlation relative to the corresponding GDP comovement. We do so by dividing the correlation of local consumption growth rates by the correlation of local output growth rates (rows 3 and 6 in Table 4). Because local consumption growth rates are less correlated across the provinces than GDP growth rates for the pre-reform period, the ratio is statistically significantly below unity. By comparison, the corresponding ratios for the OECD economies in the two periods are not significantly different from one (row 6, Table 4). This suggests that, after accounting for output co-movements, consumption risk sharing appears to be lower across Chinese regions than across the OECD countries.

Columns 3 and 6 of Table 4 report the results from some difference-in-mean test of the change in the correlations between the time periods, and between the 1980s and the 1990s. Because the output correlation decreases to a larger extent, the relative consumption correlation in China increases in the sample (by 0.054 ), but this change is not statistically different from zero.

Furthermore, if one splits the reform period into two parts, 1980s and 1990s, a somewhat surprising pattern emerges (Table 4, Columns 4 and 5). The consumption correlation declines markedly (from 0.70 to 0.21 ) while the output correlation increases (from 0.63 to 0.72 , rows 1 and 2). Those two opposing movements lead to a sharp drop in the relative consumption correlation from 1.10 (indicated a high consumption risk sharing in the 1980s) to 0.30 (Row 3, Columns 4 and 5 in Table 6). This decline is statistically significant (Row 3, Column 6). If one performs a similar computation for the OECD countries, one finds that there is also a moderate decline in the relative consumption correlation (Row 6, Columns 4 and 5). However, unlike the Chinese case, this decline is not statistically different from zero. In other words, there is a significant decline in the extent of consumption risk sharing across Chinese regions over the last twenty years.

As an alternative measure of consumption risk sharing, one can look at the average consumption volatility relative to average output volatility. A higher degree of consumption risk 
sharing across geographic units would imply a lower relative consumption volatility. Table 5 reports the average volatilities of per capita consumption and output growth rates across the Chinese provinces as well as across OECD countries for comparison. Consumption and output volatilities are reported in rows 1 and 2 respectively. Generally, there is a significant decline in the volatility of consumption and output in the reform period compared to the pre-reform era. The relative consumption volatilities with respect to output volatilities for China and for OECD countries are reported in Rows 3 and 6 in Table 8, respectively. The relative consumption volatility within China is in the same range as the corresponding measure across OECD countries. If one breaks down the reform period into the two decades, one finds that the relative consumption volatility in China has increased, rather than decreased, from 1.23 in the 1980s to 1.38 in the 1990s (Row 3, Columns 4 and

5), though the increase is not statistically significant. This suggests that the risk sharing opportunities have not improved over the last ten years.

To summarize, both the evidence on relative consumption correlation (regional consumption correlation relative to that of regional output correlation) and the evidence on relative consumption volatility (average consumption volatility relative to output volatility) appear to suggest that the degree of risk sharing across the Chinese regions is not high and has not improved from the 1980s to the 1990s. However, these measures are not conclusive per se. A low degree of capital mobility can come from a low degree of financial integration within China, but also from incompleteness of the asset market. This will be dealt with in the next sub-section.

\section{c) Conditional Test of Risk Sharing}

We follow a model developed by Obstfeld (1994) that allows testing for capital mobility when asset markets are incomplete. The basic specification is:

$$
d \ln \left(C_{i t}\right)=a+b d \ln \left(C_{-i t}\right)+c d \ln \left(\operatorname{LRL}_{i t}\right)+u_{i}+e_{i t}
$$

where $\mathrm{C}_{\mathrm{it}}$ is per capita private consumption in real terms, $\mathrm{C}_{\text {-it }}$ is per capita private consumption in the rest of the country $i, u_{i}$ is the provincial fixed effect and $e_{i t}$ is the error term. The term $L_{R L} L_{i t}$ stands for "Local Resource Limit" in per capita terms, and is defined as $\mathrm{GDP}_{\mathrm{it}}-\mathrm{I}_{\mathrm{it}}-\mathrm{G}_{\mathrm{it}}$, where $\mathrm{I}_{\mathrm{it}}$ and $\mathrm{G}_{\mathrm{it}}$ are investment rate and government consumption (per capita), respectively. It corresponds to the maximum consumption level when capital mobility is zero. In other words, if local consumption is rigidly constrained by the local resource limit at a given point in time, then $b=0$ and $c=1$. On the other hand, if cross-regional degree of financial integration is high, we would expect $b$ to be closer to one 
and c closer to zero. Intuitively, equation (3) gives an indication of the extent to which consumption is relatively more closely related to global or local factors represented, respectively, by the average consumption outside the region, $\mathrm{C}_{\text {-it }}$, and the local resource limit, $\mathrm{LRL}_{\text {it. }}{ }^{18}$

Table 6 reports the estimation results. The null hypothesis of perfect financial integration $(b=1$ and $c=0)$ is rejected for both the pre-reform and the reform periods. At the opposite extreme, the hypothesis of no financial integration is also rejected $(b=0$ and $c=1)$. In fact, there is some modest improvement in financial integration from 1952-77 to 1978-2001. However, within the last period, there is no evidence of increasing financial integration from the first sub-period (1978-89) to the last (1990-2001).

For comparison, we computed the corresponding tests for consumption risksharing across OECD countries and report them in Table 7. The coefficient on other countries' average consumption increases steadily over time from 0.35 during $1960-1977$ to 0.60 during 1978-99. It increases within the last period as well, reaching 0.90 in the 1990s. Correspondinglym, the coefficient on the Domestic Resource Limit (DRLit, akin to the LMR for the China regression) decreases steadily, from 0.43 during 1960-1977, to 0.24 during $1978-89$, and finally to 0.08 in the 1990 s.

To summarize, while evidence of increasing financial integration is clear across the OECD countries, it is much less so across the regions within China. If anything, the degree of intra-China consumption rish sharing might have declined during the last two decades.

\section{d) Was There Any Improvement in Capital Mobility in the 1990s?}

We have shown so far that there is no evidence of an improvement in capital mobility from the 1980 s to the 1990s. Several reforms in the early and mid-1990s could have the effect of improving capital mobility. We are thus interested in checking whether capital mobility has increased within the 1990s. We do so by breaking the last period in the sample (1990-2001) into two subperiods (1990-1995 and 1996-2001) and testing for any significant change in the investment-saving correlation or consumption smoothing over time. The results are reported in Table 8.

On the question of whether local investment is constrained by local savings, neither the conditional nor the unconditonal tests (lines 1-4 in Panel A of Table 8) detect any improvement in financial integration during the 1990s. The picture is somewhat different (and less clear cut) when it

\footnotetext{
${ }^{18} \mathrm{We}$ also introduced aggregate output growth as a regressor and obtained very similar results.
} 
comes to consumption risk sharing. There is actually a statistically significant improvement in risk sharing in the late 1990s as shown by the increase in the ratio of consumption correlation to output correlation (line 5 in Table 8, Panel 8). However, the extent of consumption smoothing in the late 1990s is still much lower than in the 1980s (as reported in Tables 4 and 5). Furthermore, no significant decline in the consumption volatility relative to income volatility can be detected (line 6 of Table 8). Finally, Panel B of Table 8 reports the results from a conditional test of consumption risksharing. There is some evidence of increasing correlation in consumption across regions and of declining reliance on a region's own local resources for consumption.

Overall, capital mobility may have improved moderately from the first half of the 1990s to the second half. However, this mainly results from a recovery of the lost ground in the early 1990s rather than any significant progress relative to the 1980s.

\section{Does Capital Flow to More Productive Regions?}

At this juncture, it is useful to point out that capital mobility and efficiency of capital allocation need not be the same thing. For example, if local savings used to be randomly reshuffled by the central government under a planned-economy framework, then a move from an inefficient planned economy to a more efficient market economy could give an appearance of a reduction in capital mobility even though the efficiency of capital allocation (in terms of channelling capital to most productive investment projects) could have increased at the same time. As another example, informational asymmetry between users of funds and savers could result in low capital mobility even without any other policy-driven barriers to capital mobility.

These examples illustrate the possibility that evidence of low capital mobility does not automatically suggest low efficiency of capital allocation. In the current section, we investigate more directly, to the extent some capital moves around within China, whether it is generally allocated from less productive regions to more productive ones.

An efficient capital market is one in which capital goes to the most productive activities. In our sample, one would expect that net capital inflow into a region (relative to that region's economic size) is positively related to that region's marginal product of capital. Therefore, we estimate variations of the following specification:

$(\text { Net capital inflows })_{\mathrm{it}}=\mathrm{a}+\mathrm{b}(\text { Initial income })_{\mathrm{it}}+\mathrm{c}(\text { Marginal Product of Capital })_{\mathrm{it}}+\mathrm{u}_{\mathrm{i}}+\mathrm{e}_{\mathrm{it}}$ 
To do this, we need to compute every region's marginal product of capital. To keep it tractable, we assume that a common form of Cobb-Douglas production function with constant returns to scale applies to all provinces:

$$
Y_{j t}=A_{j t} K_{j t}^{\alpha} L_{j t}^{1-\alpha}
$$

The productivity parameter, $\mathrm{A}_{\mathrm{jt}}$, is allowed to vary across provinces and over time, but the factor share, $\alpha$, is assumed to be the same across provinces and constant. This allows us to express the marginal product of capital for any province as a constant proportion of the ratio of its output to capital stock (or the average product of capital):

$$
\mathrm{MPK}_{\mathrm{jt}}=\partial \mathrm{Y}_{\mathrm{jt}} / \partial \mathrm{K}_{\mathrm{jt}}=\alpha A K^{\alpha-1} \mathrm{~L}^{1-\alpha}=\alpha \mathrm{Y}_{\mathrm{jt}} / \mathrm{K}_{\mathrm{jt}}
$$

We make use of the provincial-level capital stock data between 1984 and 1998 estimated by Li (2003) and updated by us to 2001 to calculate marginal product of capital. ${ }^{19}$

In Column 1 of Table 9, we regress net capital inflow to a province on its marginal product of capital. The result indicates a clear lack of positive association between the two. The slope coefficient is in fact negative. This suggests that, on average, capital flows within China do not go to the most productive regions. If anything, there is a tendency for capital to go to regions where capital has lower productivity. Figure 1 illustrates this pattern visually by plotting provincial average capital inflows (scaled by regional size) over the period 1984-2001 against regional marginal capital productivity. Least productive provinces such as Ningxia, Qinghai, Xinjiang, Shaanxi have received relatively more capital inflows. In contrast, highly productive provinces such as Hebei, Sichuan Guangdong, Hunan and Fujian receive small inflows.

What can explain this peculiar pattern of capital allocation? Let us first examine the role of the government in this pattern. In our data set, the financing sources can be broken down into several different categories:

(a) Appropriation in the government budget earmarked for capital construction and projects;

(b) Loans from banks and non-bank financial institutions to local enterprises and institutions;

\footnotetext{
${ }^{19}$ See statistical annex for a description of the method used to compute provincial capital stocks and productivity.
} 
(c) Foreign Investment;

(d) "Self-raised funds" by firms from their higher responsible entities ("headquarters" or ministries) or through issuance of stocks and bonds.

(e) Others: all other investment not in the above categories.

We investigate how these various components of investment respond to local marginal product of capital. The results are reported in the last five columns in Table 9. An interesting pattern emerges. First, the investment by domestic firms based on self-raised funds do respond positively to marginal product of capital. This suggests that when investment is motivated mostly by profit maximization, it tends to go where it is most productive. FDI and self-raised funds are the only two categories of investment that exhibit a positive relationship with marginal product of capital, although the coefficient on FDI is not statistically significant. Second, investment allocated through government budget and loans made by state-owned financial institutions are (the only) two categories that exhibit a clear negative relationship with marginal productivity of capital. From these results, we conclude that it is the allocation of capital by the government that is primarily responsible for the peculiar pattern that net capital flows go to less productive regions.

Why would the government systematically allocate capital away from more productive regions toward less productive ones? A natural hypothesis is that the state has objectives other than maximizing economic efficiency. There are at least three theories one might think of: First, the government may value poverty reduction in its objective function and therefore channels capital to poor regions. If low initial incomes coincide with low capital productivity, one could see a negative association between capital inflows and capital returns.

Second, state-owned enterprises (SOEs) may act as a bottomless pits in sucking governmentchanneled investment funds. Here, one might consider two variations of the theory. Version A stresses a political-economy interpretation. SOEs may be politically more powerful than private (or other non-state) firms. Consequently, they are able to obtain more investment funds from the government, particularly through government budget allocation, even if they are not productive. Version B is a concern for employment in SOEs. Precisely because SOEs are less productive on average and have trouble competing for funds in a well-functioning and integrated capital market, the government, out of concern for unemployment consequences of SOE bankruptcy, may choose to channel the capital systematically to SOEs even if they are not productive. Of course, the two versions of the theory are not mutually exclusive. Either way, they could generate a negative 
association between capital inflows and capital productivity but a positive association between capital inflows and the importance of SOEs in local economies.

Third, the government could direct capital flows in favor of a particular industrial structure. It is understood that the Chinese central planning before 1978 systematically discriminated against the agricultural and other primary sectors in favor of industries. Since the reform started in 1978, the government rhetoric has been to extend more assistance to peasants in the countryside. If the rhetoric is reflected in the actual policy, one would see a positive association between net capital inflow into a region and the importance of the primary sector in the local economy (which might have lower marginal return to capital).

We undertake an examination of these theories and report the results in Table 10. In the first column, net capital inflows respond positively to the share of state production in the province and negatively to the share of agriculture. In the subsequent columns of Table 10, we examine the connections between various components of local investment and the initial income, the share of SOEs in local industrial output, and the share of the primary sector in local output.

A few results emerge. First, there is no negative and statistically significant effect of initial income on investment. In other words, if the investment funds are systematically channeled to poorer regions, the effect is not large enough to be picked up by the data. Second, interestingly, the share of SOEs in local industrial production has a clear positive and statistically significant effect on the size of investment allocated by government budget or financed by bank loans. So the importance of stateowned firms in the local economy is a significant factor in explaining investment patterns from these two sources. In contrast, the share of SOEs has a negative sign in the FDI equation, suggesting that the presence of SOEs may act as a barrier to FDI. Third, the share of the primary sector in local GDP is not significant in any regression. This suggests that capital allocation in China neither favors nor discriminates against the primary sector on average.

To conclude, the strongest determinant of capital allocation rule in China appears to be the relative prominence of state-owned firms in local economies. SOEs generally grow more slowly than private (and other non-SOE) sector(s) of the economy. Therefore, an investment allocation rule by the government that favors SOEs would allocate capital systematically away from the more productive regions toward less productive ones. In this sense, a smaller role of the government in the allocation of capital might increase the efficiency and growth rate of the economy. 


\section{CONCluding Remarks}

The Chinese experience has been invoked by some in the literature to suggest that an effective financial system does not necessarily depend on standard institutions. This paper studies some pitfalls of a state-dominated financial system using the case of China. In particular, it examines the degree to which capital markets are segmented within the country due to the interference of the local governments; it also examines whether state-dominated financial system may perversely channel funds away from productive regions toward less productive ones.

This paper casts doubt on the view that the Chinese financial system functions effectively. Our results indicate that capital is much less mobile within China than within countries known to have integrated international capital markets. Perhaps most surprisingly, we find that the degree of capital mobility in China significantly decreased in the 1990s relative to the 1980s. Furthermore, we document that the government (as opposed to the private sector) tends to systematically reallocate capital from more productive regions to less productive ones. These findings suggest that a smaller role of the government in the financial system is likely to improve the efficiency of the economy. 


\section{Statistical Appendix}

The provincial data series consists of provincial GDP desegregated into household and government consumptions, gross capital formation, changes in inventory and net exports. The sources are:

- $\quad$ A11 China Marketing Research, 2001, 1949-1999 China Statistical Data Compilation.

- $\quad$ China State Statistical Bureau, 1996, China Regional Economy, a Profile of 17 years of Reform and Opening-up, China State Statistical Bureau Publishing House, Beijing.

- $\quad$ China State Statistical Bureau, 2000 and 2001, China Statistical Yearbook, China State Statistical Bureau Publishing House, Beijing.

The data set includes 28 provinces (or province-level autonomous regions or super-cities) during 1978-2001, and 24 provinces during 1952-1977.

List of provinces in the sample (1978-2001) : Beijing, Tianjin, Hebei, Shanxi, Nei Monggol, Liaoning, Jilin, Heilongjiang, Shanghai, Jiangsu, Zhejiang, Anhui, Fujian, Jiangxi, Shandong, Henan, Hubei, Hunan, Guangxi, Guizhou, Yunnan, Shaanxi, Gansu, Qinghai, Ningxia, Xinjiang, Guangdong+Hainan, Sichuan+Chongqing.

List of provinces in the sample (1952-1977): Jiangxi, Guangdong and Hainan, Sichuan and Chongqing and Ningxia have been excluded for the pre-reform period because of lack of data. Tianjin is excluded for the period 1952-1977 because population data are not available.

The national account data (consumption, investment, saving, GDP) for OECD come from United Nations Statistical Office, UN National Accounts. The dataset includes 24 OECD countries: Australia, Austria, Belgium, Canada, Denmark, Finland, France, Germany, Greece, Iceland, Ireland, Italy, Japan, Korea, Luxembourg, Netherlands, New Zealand, Norway, Portugal, Spain, Sweden, Switzerland, United Kingdom, United States. 
Table 1: Unconditional FH Test: Chinese Provinces Versus OECD Countries

\begin{tabular}{|c|c|c|c|c|c|c|c|c|}
\hline & & (1) & (2) & $(3)=(2)-(1)$ & (4) & (5) & $(6)=(5)-(4)$ & \\
\hline & China & 1952-1977 & 1978-2001 & Difference & 1978-1989 & 1990-2001 & Difference & \\
\hline (1) & $\begin{array}{l}\text { Investment-saving } \\
\text { correlation\# }\end{array}$ & $\begin{array}{r}0.534 \\
(0.062)\end{array}$ & $\begin{array}{r}0.525 \\
(0.091)\end{array}$ & $\begin{array}{r}-0.027 \\
(0.092)\end{array}$ & $\begin{array}{r}0.300 \\
(0.102)\end{array}$ & $\begin{array}{c}0.5991 \\
(0.0841) * *\end{array}$ & $\begin{array}{r}0.299 \\
(0.120)\end{array}$ & $* * *$ \\
\hline & OECD & 1960-1977 & 1978-1999 & Difference & 1978-1989 & 1990-1999 & Difference & \\
\hline (2) & $\begin{array}{l}\text { Investment-saving } \\
\text { correlation\# }\end{array}$ & $\begin{array}{r}0.717 \\
(0.067)\end{array}$ & $\begin{array}{r}0.457 \\
(0.069)\end{array}$ & $\begin{array}{c}0.118 \\
(0.078)^{*}\end{array}$ & $\begin{array}{r}0.413 \\
(0.099)\end{array}$ & $\begin{array}{r}0.483 \\
(0.094)\end{array}$ & $\begin{array}{r}0.069 \\
(0.138)\end{array}$ & \\
\hline
\end{tabular}

Sources: For data on China, A11 China Marketing Research, 2001; 1949-1999 China Statistical Data Compilation, China Statistical Bureau, Beijing; and China Statistical Yearbook, various years, China Statistical Bureau, Beijing. For data on the OECD countries: UN National Accounts, World Development Indicators.

Notes:

1. \# calculated as average time correlation between regional investment and saving rates (in percent GDP).

2. $*(* *, * *)$ denotes significant at the 10 percent $(5$ percent, 1 percent) level.

3. Standard errors are in parentheses. 
Table 2: Conditional FH Test

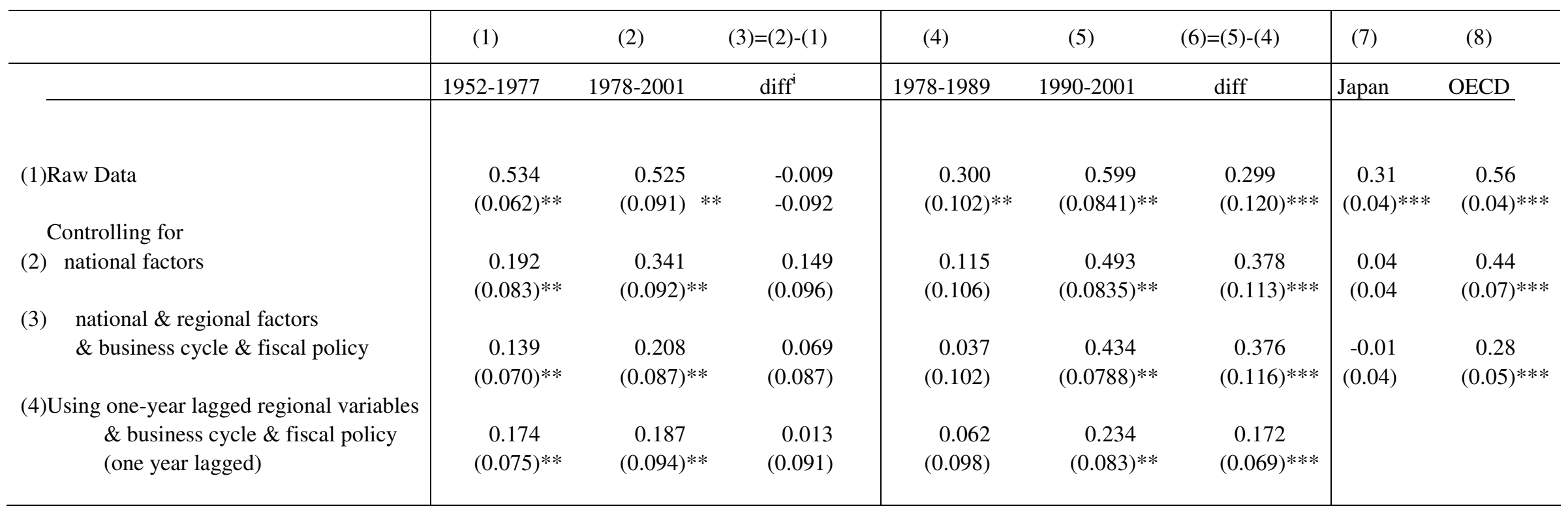

Source: Columns 1-6, the authors' calculations; Columns 7 and 8, from Iwamoto and van Wincoop (2000).

$*(* *, * * *)$ significant at the 10 percent (5 percent, 1 percent) level.

Standard errors in parentheses

${ }^{\mathrm{i}}$ reports the mean of the difference between pairwise correlations of the 2 sub-periods. 
Table 3: Conditional FH Test-Banking Data: Chinese Provinces Versus OECD Countries

\begin{tabular}{|c|c|c|c|}
\hline \multirow[b]{2}{*}{ China } & (1) & (2) & $(3)=(2)-(1)$ \\
\hline & 1978-1989 & 1990-2001 & Difference \\
\hline (1) Raw data & $\begin{array}{c}0.664 \\
(0.067)^{* *}\end{array}$ & $\begin{array}{c}0.505 \\
(0.078)^{* *}\end{array}$ & $\begin{array}{c}-0.159 \\
(0.098)^{*}\end{array}$ \\
\hline (2)Controlling for national factors & $\begin{array}{c}0.301 \\
(0.110)^{* *}\end{array}$ & $\begin{array}{c}0.596 \\
(0.091)^{* *}\end{array}$ & $\begin{array}{c}0.295 \\
(0.125) * *\end{array}$ \\
\hline (3) national \& regional factors & $\begin{array}{c}0.435 \\
(0.094)^{* *}\end{array}$ & $\begin{array}{c}0.580 \\
(0.095)^{* *}\end{array}$ & $\begin{array}{c}0.145 \\
(0.084) *\end{array}$ \\
\hline & (1) & (2) & $(3)=(2)-(1)$ \\
\hline & 1978-1989 & 1990-2001 & Difference \\
\hline (1)Raw Data & $\begin{array}{c}0.630 \\
(0.087)^{* *}\end{array}$ & $\begin{array}{c}0.617 \\
(0.087)^{* *}\end{array}$ & $\begin{array}{r}-0.013 \\
(0.147)\end{array}$ \\
\hline (2)Controlling for global factors & $\begin{array}{c}0.675 \\
(0.081)^{* *}\end{array}$ & $\begin{array}{c}0.241 \\
(0.114)^{* *}\end{array}$ & $\begin{array}{c}-0.434 \\
(0.095) * *\end{array}$ \\
\hline (3)Global \& national factors & $\begin{array}{c}0.675 \\
(0.084)^{* *}\end{array}$ & $\begin{array}{c}0.285 \\
(0.116)^{* *}\end{array}$ & $\begin{array}{c}-0.390 \\
(0.116) *\end{array}$ \\
\hline
\end{tabular}

Source: Authors' calculations.

$*(* *, * * *)$ denotes significant at the 10 percent (5 percent, 1 percent) level. Standard errors are in parentheses. 
Table 4: Unconditional Test of Risk Sharing-Consumption Correlations: Chinese Provinces Versus OECD Countries

\begin{tabular}{|c|c|c|c|c|c|c|}
\hline & $(1)$ & $(2)$ & $(3)=(2)-(1)$ & $(4)$ & $(5)$ & $(6)=(5)-(4)$ \\
\hline China & $1952-1977$ & $1978-2001$ & Difference & 1978-1989 & 1990-2001 & Difference \\
\hline (1)Correlation of consumption & $\begin{array}{r}0.621 \\
(0.028)\end{array}$ & $\begin{array}{r}0.541 \\
(0.031)\end{array}$ & $\begin{array}{l}-0.080 * * * \\
(0.028)\end{array}$ & $\begin{array}{r}0.698 \\
(0.030)\end{array}$ & $\begin{array}{r}0.213 \\
(0.063)\end{array}$ & $\begin{array}{l}-0.485 * * * \\
(0.069)\end{array}$ \\
\hline (2)Correlation of output & $\begin{array}{r}0.800 \\
(0.020)\end{array}$ & $\begin{array}{r}0.652 \\
(0.028)\end{array}$ & $\begin{array}{l}-0.148 * * * \\
(0.038)\end{array}$ & $\begin{array}{r}0.633 \\
(0.038)\end{array}$ & $\begin{array}{r}0.723 \\
(0.043)\end{array}$ & $\begin{array}{l}0.090 * * * \\
(0.048)\end{array}$ \\
\hline $\begin{array}{l}\text { (3)Ratio of consumption. } \\
\text { to output correlations } \\
=(1) /(2)\end{array}$ & $\begin{array}{r}0.776 \\
(0.042)\end{array}$ & $\begin{array}{r}0.828 \\
(0.047)\end{array}$ & $\begin{array}{l}0.052 \\
0.068\end{array}$ & $\begin{array}{r}1.103 \\
(0.111)\end{array}$ & $\begin{array}{r}0.295 \\
(0.102)\end{array}$ & $\begin{array}{l}-0.808 * * * \\
(0.160)\end{array}$ \\
\hline OECD & $1960-1977$ & 1978-1999 & Difference & 1978-1989 & 1990-1999 & Difference \\
\hline (4)Correlation of consumption & $\begin{array}{r}0.352 \\
(0.044)\end{array}$ & $\begin{array}{r}0.352 \\
(0.042)\end{array}$ & $\begin{array}{r}0.000 \\
(0.048)\end{array}$ & $\begin{array}{r}0.411 \\
(0.060)\end{array}$ & $\begin{array}{r}0.355 \\
(0.067)\end{array}$ & $\begin{array}{r}-0.056 \\
(0.099)\end{array}$ \\
\hline (5)Correlation of output & $\begin{array}{r}0.423 \\
(0.053)\end{array}$ & $\begin{array}{r}0.384 \\
(0.043)\end{array}$ & $\begin{array}{r}0.038 \\
(0.055)\end{array}$ & $\begin{array}{r}0.437 \\
(0.062)\end{array}$ & $\begin{array}{r}0.444 \\
(0.074)\end{array}$ & $\begin{array}{r}0.007 \\
(0.101)\end{array}$ \\
\hline $\begin{array}{l}\text { (6)Ratio of consumption. } \\
\text { to output correlations } \\
=(4) /(5)\end{array}$ & $\begin{array}{r}0.832 \\
(0.464)\end{array}$ & $\begin{array}{r}0.917 \\
(0.138)\end{array}$ & $\begin{array}{r}0.084 \\
(0.428)\end{array}$ & $\begin{array}{r}0.941 \\
(0.146)\end{array}$ & $\begin{array}{r}0.800 \\
(0.442)\end{array}$ & $\begin{array}{r}-0.141 \\
(0.514)\end{array}$ \\
\hline
\end{tabular}

Sources: See the footnotes to Table 2.

$*(* *, * * *)$ significant at the 10 percent (5 percent, 1 percent) level (indicated only for the difference in mean tests in Columns 3 and 6 .

Standard errors in parentheses. 
Table 5: Unconditional Test of Risk Sharing-Consumption Volatilities: Chinese Provinces Versus OECD Countries

\begin{tabular}{|c|c|c|c|c|c|c|}
\hline China & $\begin{array}{c}(1) \\
1952-1977 \\
\end{array}$ & $\begin{array}{c}(2) \\
1978-2001 \\
\end{array}$ & $\begin{array}{l}(3)=(2)-(1) \\
\text { Difference }\end{array}$ & $\begin{array}{c}(4) \\
1978-1989 \\
\end{array}$ & $\begin{array}{c}(5) \\
1990-2001 \\
\end{array}$ & $\begin{array}{l}(6)=(5)-(4) \\
\text { Difference }\end{array}$ \\
\hline (1) Volatility of consumption & $\begin{array}{r}9.18 \\
(1.09)\end{array}$ & $\begin{array}{r}5.58 \\
(0.202)\end{array}$ & $\begin{array}{l}-3.60 * * * \\
(1.11)\end{array}$ & $\begin{array}{r}5.63 \\
(0.22)\end{array}$ & $\begin{array}{r}5.07 \\
(0.32)\end{array}$ & $\begin{array}{l}-0.56 * * * \\
(0.39)\end{array}$ \\
\hline (2)Volatility of output & $\begin{array}{l}14.15 \\
(0.79)\end{array}$ & $\begin{array}{r}4.23 \\
(0.15)\end{array}$ & $\begin{array}{l}-9.92 * * * \\
(0.84)\end{array}$ & $\begin{array}{r}4.57 \\
(0.23)\end{array}$ & $\begin{array}{r}3.66 \\
(0.24)\end{array}$ & $\begin{array}{l}-0.91 * * * \\
(0.34)\end{array}$ \\
\hline $\begin{array}{l}\text { (3)Ratio of consumption. } \\
\text { to output volatilities }\end{array}$ & $\begin{array}{r}0.65 \\
(0.28)\end{array}$ & $\begin{array}{r}1.32 \\
(0.14)\end{array}$ & $\begin{array}{l}0.67 * * * \\
(0.26)\end{array}$ & $\begin{array}{r}1.23 \\
(0.14)\end{array}$ & $\begin{array}{r}1.38 \\
(2.12)\end{array}$ & $\begin{array}{r}0.15 \\
(2.20)\end{array}$ \\
\hline OECD & $1960-1977$ & 1978-1999 & Difference & $1978-1989$ & 1990-1999 & Difference \\
\hline (4)Volatility of consumption & 2.61 & 2.15 & $-0.46^{*}$ & 2.25 & 1.84 & $-0.41 * *$ \\
\hline $\operatorname{Std}(\mathrm{Cit})$ & $(0.36)$ & $(0.18)$ & $(0.252)$ & $(0.233)$ & $(0.17)$ & $(0.21)$ \\
\hline (5) Volatility of output & 2.71 & 1.98 & $-0.73 * * *$ & 1.96 & 1.86 & -0.10 \\
\hline Std(Yit) & $(0.22)$ & $(0.12)$ & $(0.192)$ & $(0.13)$ & $(0.16)$ & $(0.19)$ \\
\hline (6)Ratio of consumption. & 0.96 & 1.09 & $0.12 * * *$ & 1.15 & 0.99 & $-0.16^{*}$ \\
\hline to output volatilities & $(0.07)$ & $(0.07)$ & $(0.05)$ & $(0.09)$ & (1.17) & $(0.09)$ \\
\hline
\end{tabular}

Sources: See the footnotes to Table 2

Volatility is defined as standard deviation of the first difference in log per capita consumption (or GDP) for each province (country).

$*(* *, * * *)$ significant at the 10 percent (5 percent, 1 percent) level.

Standard errors in parentheses. 
Table 6: Conditional Test of Risk Sharing_-Incomplete Asset Market: Chinese Provinces (Dependent Variable: Logarithm of Per Capita Real Consumption)

\begin{tabular}{|c|c|c|c|c|}
\hline Period & 1952-1977 & 1978-2001 & 1978-1989 & 1990-2001 \\
\hline $\mathrm{d} \ln (\mathrm{C}-\mathrm{it})-(\mathrm{b})$ & $\begin{array}{l}0.722^{* * * *} \\
(0.070)\end{array}$ & $\begin{array}{l}0.867^{* * * *} \\
(0.051)\end{array}$ & $\begin{array}{l}0.878 * * * \\
(0.051)\end{array}$ & $\begin{array}{l}0.672 * * \\
(0.219)\end{array}$ \\
\hline $\mathrm{d} \ln (\mathrm{LRLt})-(\mathrm{c})$ & $\begin{array}{l}0.277^{* * * *} \\
(0.055)\end{array}$ & $\begin{array}{l}0.033 * * * \\
(0.0186)\end{array}$ & $\begin{array}{l}0.056 * * * \\
(0.012)\end{array}$ & $\begin{array}{l}0.140 * * \\
(0.019)\end{array}$ \\
\hline adj. r2 & 0.92 & 0.29 & 0.49 & 0.12 \\
\hline \# obs & 597 & 665 & 330 & 335 \\
\hline \# provinces & 23 & 28 & 28 & 28 \\
\hline $\mathrm{H} 1: \mathrm{b}=1$ & $\mathrm{~F}(1,562)=15.62 * * *$ & $\mathrm{~F}(1,635)=6.48 * * *$ & $\mathrm{~F}(1,300)=5.72 * *$ & $F(1,305)=2.23$ \\
\hline $\mathrm{H} 2: \mathrm{c}=1$ & $\mathrm{~F}(1,562)=171.4 * * *$ & $\mathrm{~F}(1,635)=2605 * * *$ & $\mathrm{~F}(1,300)=6429 * * *$ & $\mathrm{~F}(1,305)=2663 * * *$ \\
\hline $\mathrm{H} 3: \mathrm{b}=1 \& \mathrm{c}=0$ & $\mathrm{~F}(2,562)=12.72 * * *$ & $\mathrm{~F}(2,635)=3.86^{* *}$ & $\mathrm{~F}(2,300)=13.64 * * *$ & $\mathrm{~F}(2,305)=1.50$ \\
\hline $\mathrm{H} 4: \mathrm{b}=0 \quad \& \quad \mathrm{c}=1$ & $\mathrm{~F}(2,562)=86.22 * * *$ & $\mathrm{~F}(2,635)=1310 * * *$ & $\mathrm{~F}(2,300)=3306 * * *$ & $\mathrm{~F}(2,305)=1331 * * *$ \\
\hline
\end{tabular}

Source: Authors' calculations.

C-it: per capita real consumption outside province i. LRLit= Yit - Iit - Git (Local Resource Limit), Yit: per capita real GDP, Iit: provincial per capita real investment, Git: provincial per capita government real consumption, ln: logarithm, d: first difference

$*(* *, * * *)$ significant at the 10 percent (5 percent, 1 percent) level. All the regressions include fixed provincial effects. Robust standard errors in parentheses. 
Table 7: Conditional Test of Risk Sharing-Incomplete Asset Market: OECD Countries (Dependent Variable: Logarithm of Per Capita Household Real Consumption)

\begin{tabular}{|c|c|c|c|c|c|c|c|c|}
\hline Period & $1960-1977$ & & 1978-1999 & & 1978-1989 & & 1990-1999 & \\
\hline \multirow{2}{*}{$\mathrm{dln}(\mathrm{C}-\mathrm{it})-(\mathrm{b})$} & \multicolumn{2}{|c|}{$0.354 * * *$} & \multicolumn{2}{|c|}{$0.629 * * *$} & \multicolumn{2}{|c|}{$0.600 * * *$} & \multicolumn{2}{|c|}{$0.897 * * *$} \\
\hline & \multicolumn{2}{|c|}{$(0.101)$} & \multicolumn{2}{|c|}{$(0.097)$} & \multicolumn{2}{|c|}{$(0.113)$} & \multicolumn{2}{|c|}{$(0.252)$} \\
\hline \multirow[t]{2}{*}{ dln(DRLit) - (c) } & \multicolumn{2}{|c|}{$0.425 * * *$} & \multicolumn{2}{|c|}{$0.203 * * *$} & \multicolumn{2}{|c|}{$0.239 * * *$} & \multicolumn{2}{|c|}{0.081} \\
\hline & \multicolumn{2}{|c|}{$(0.079)$} & \multicolumn{2}{|c|}{$(0.072)$} & \multicolumn{2}{|c|}{$(0.089)$} & \multicolumn{2}{|c|}{$(0.108)$} \\
\hline adj. r2 & \multicolumn{2}{|c|}{0.34} & \multicolumn{2}{|c|}{0.18} & \multicolumn{2}{|c|}{0.31} & \multicolumn{2}{|c|}{0.21} \\
\hline \# obs & \multicolumn{2}{|c|}{381} & \multicolumn{2}{|c|}{528} & \multicolumn{2}{|c|}{288} & \multicolumn{2}{|r|}{240} \\
\hline \# countries & \multicolumn{2}{|c|}{24} & \multicolumn{2}{|c|}{24} & \multicolumn{2}{|c|}{24} & \multicolumn{2}{|r|}{24} \\
\hline $\mathrm{H} 1: \mathrm{b}=1$ & $F(1,355)=40.68$ & $* * *$ & $F(1502)=14.78$ & $* * *$ & $F(1,262)=12.74$ & $* * *$ & $\mathrm{~F}(1,214)=0.17$ & \\
\hline $\mathrm{H} 2: \mathrm{c}=1$ & $F(1,355)=52.45$ & $* * *$ & $\mathrm{~F}(1,502)=122.51$ & $* * *$ & $F(1,262)=73.82$ & $* * *$ & $F(1,214)=71.53$ & $* * *$ \\
\hline $\mathrm{H} 3: \mathrm{b}=1 \& \mathrm{c}=0$ & $F(2,355)=31.95$ & $* * *$ & $\mathrm{~F}(2,502)=9.59$ & $* * *$ & $\mathrm{~F}(2,262)=7.99$ & $* * *$ & $\mathrm{~F}(2,214)=0.37$ & \\
\hline $\mathrm{H} 4: \mathrm{b}=0 \quad \& \mathrm{c}=1$ & $F(2,355)=30.39$ & $* * *$ & $F(2,502)=70.86$ & $* * *$ & $F(2,262)=41.69$ & $* * *$ & $\mathrm{~F}(2,214)=42.42$ & $* * *$ \\
\hline
\end{tabular}

Source: Authors' calculations.

Notes:

1. All the regressions include fixed country effects. Robust standard errors are in parentheses. *(**,***) denotes significant at the 10 (5 and 1$)$ percent level.

2. $\mathrm{C}$-it = per capita real consumption outside province i; LRLit= Yit - Iit - Git (Local Resource Limit); Yit: per capita household real GDP. Iit=provincial per capita real investment; Git=provincial per capita government real consumption. Ln deotes logarithm, and d(.) represents first difference.

3. H1: the consumption (C-it) coefficient $b=1$ (high degree of risk-sharing).

$\mathrm{H} 2$ : the local resource limit (LRLit) coefficient $\mathrm{c}=1$ (low degree of risk-sharing).

H3: joint test that the consumption coefficient $(C-i t)=1$ and the local resource limit (LRLit) coefficient $=0$ (high degree of risk-sharing).

H4: joint test that the consumption coefficient $(\mathrm{C}$-it $)=0$ and the local resource limit (LRLit) coefficient $=1$ (low degree of risk-sharing) 
Table 8: Capital Mobility in the 1990s

\begin{tabular}{lrrr}
\hline \multicolumn{1}{c}{ Panel A } & \multicolumn{2}{c}{$(1)$} & \multicolumn{2}{c}{$(2)$} & $(3)=(2)-(1)$ \\
& $1990-1995$ & $1996-2001$ & \multicolumn{1}{c}{ diff. } \\
\hline (1)Investment-saving correlation (unconditional) & 0.611 & 0.585 & 0.026 \\
& $(0.100)$ & $(0.081)$ & $(0.119)$ \\
& 0.361 & 0.425 & 0.063 \\
(2)Investment-saving correlation (conditional) & $(0.110)$ & $(0.098)$ & $(0.139)$ \\
& 0.439 & 0.569 & 0.130 \\
(3)Deposit-Loans correlation (unconditional) & $(0.098)$ & $(0.082)$ & $(0.118)$ \\
& 0.492 & 0.580 & 0.088 \\
(4)Deposit-Loans correlation (conditional) & $(0.089)$ & $(0.100)$ & $(0.096)$ \\
& -0.027 & 0.289 & $0.541 * * *$ \\
(5)Risk-Sharing-Consumption to output correlations (unconditional) & $(0.122)$ & $(0.182)$ & $(0.031)$ \\
& 1.730 & 2.110 & 0.380 \\
(6)Risk-Sharing-Consumption to output volatilities (unconditional) & $(0.273)$ & $(0.216)$ & $(0.290)$
\end{tabular}

\begin{tabular}{|c|c|c|}
\hline Panel B & 1990-1995 & 1996-2001 \\
\hline \multicolumn{3}{|c|}{ Risk-Sharing (Conditional) } \\
\hline \multirow[t]{2}{*}{$\mathrm{d} \ln (\mathrm{C}-\mathrm{it})$} & 0.334 & $0.808 * * *$ \\
\hline & $(0.368)$ & $(0.249)$ \\
\hline \multirow[t]{2}{*}{$\operatorname{dln}(\mathrm{LRLt})$} & $0.172 * * *$ & 0.007 \\
\hline & $(0.044)$ & $(0.103)$ \\
\hline adj. r2 & 0.28 & 0.20 \\
\hline \# obs & 168 & 167 \\
\hline \# provinces & 28 & 28 \\
\hline $\mathrm{H} 3: \mathrm{b}=1 \& \mathrm{~d}=0$ & $\mathrm{~F}(2,138)=8 \cdot 17 * * *$ & $F(2,137)=0.55$ \\
\hline $\mathrm{H} 4: \mathrm{b}=0 \quad \& \quad d=1$ & $\mathrm{~F}(2,138)=175.9 * * *$ & $\mathrm{~F}(2,137)=4906 * * *$ \\
\hline
\end{tabular}

Source: Authors' calculations.

Note: See the footnotes to Table 6 . 
Table 9: Capital Flows and Capital Productivity

\begin{tabular}{|c|c|c|c|c|c|c|}
\hline & \multirow[b]{2}{*}{ net capital inflows } & \multicolumn{5}{|c|}{ Investment by source of funds } \\
\hline & & State budget & Bank loans & $\begin{array}{c}\text { Foreign } \\
\text { Investment }\end{array}$ & $\begin{array}{c}\text { Self-raised } \\
\text { Funds }\end{array}$ & Other \\
\hline \multirow[t]{2}{*}{ Initial GDP per capita } & $-0.03 *$ & $-0.007 * *$ & $-0.024 * * *$ & -0.001 & $0.030 * *$ & 0.012 \\
\hline & $(0.01)$ & $(0.003)$ & $(0.05)$ & $(0.003)$ & $(0.011)$ & $(0.008)$ \\
\hline \multirow[t]{2}{*}{ Marginal product of capital } & $-0.28 *$ & $-0.15 * * *$ & $-0.15 * * *$ & 0.05 & $0.16^{* *}$ & 0.004 \\
\hline & $(0.15)$ & $(0.04)$ & $(0.05)$ & $(0.09)$ & $(0.07)$ & $(0.042)$ \\
\hline Sargan test & 3.15 & 12.48 & 0.52 & 10.63 & 3.082 & 4.157 \\
\hline $\mathrm{AR}(2)$ test & -0.87 & $-2.90 * *$ & -1.494 & -1.179 & -2.220 & 1.611 \\
\hline \# provinces & 25 & 22 & 20 & 22 & 20 & 20 \\
\hline \#obs & 100 & 85 & 77 & 85 & 77 & 74 \\
\hline
\end{tabular}

Source: Authors' calculations.

Notes:

1. Estimated by a GMM system estimator. All regressions use robust standard errors reported in parenthesis.

2. All dependent variables are expressed as a ratio of provincial GDP. Net capital inflows are calculated by subtracting net investment from net savings in the province. "State budget" refers to appropriation in the government budget earmarked for capital construction and innovation projects, and for the transfer fund to banks to be issued as loans for earmarked projects. "Bank loans" refers to various funds borrowed by enterprises and institutions from banks and non-bank financial institutions for investment in fixed assets. "Foreign investment" refers to foreign funds received for investment in fixed assets. "Self-raised funds" refer to funds received by enterprises from their higher responsible authorities, local government or raised by enterprises or institutions themselves for the purpose of investment in fixed assets. Others refer to fund received which are not included in the above mentioned sources. Initial GDP par capita is GDP per capita in 1978 (logarithm). The Sargan (1964) test of overidentifying restrictions is a joint test of the model specification and the validity of instruments (i.e. tests if the moment conditions are respected). 
Table 10: Determinants of Capital Inflows

\begin{tabular}{|c|c|c|c|c|c|c|}
\hline & \multirow{2}{*}{$\begin{array}{l}\text { net capital } \\
\text { flows }\end{array}$} & \multicolumn{5}{|c|}{ Investment by source of funds } \\
\hline & & state budget & bank loans & FDI & Fundraising & Other \\
\hline Initial GDP per capita & $\begin{array}{l}-0.06^{* *} \\
0.02\end{array}$ & $\begin{array}{r}-0.01 \\
0.01\end{array}$ & $\begin{array}{c}0.01 \text { *** } \\
0.018\end{array}$ & $\begin{array}{l}0.00967 \\
0.00834\end{array}$ & $\begin{array}{l}0.022 * * * \\
0.021\end{array}$ & $\begin{array}{r}-0.010 \\
0.020\end{array}$ \\
\hline $\begin{array}{l}\text { Share of state firms } \\
\text { in industrial production }\end{array}$ & $\begin{array}{l}0.13^{*} \\
0.07\end{array}$ & $\begin{array}{l}0.07 * * * \\
0.01\end{array}$ & $\begin{array}{l}0.05^{*} \\
0.029\end{array}$ & $\begin{array}{l}-0.025 * * * \\
0.0084\end{array}$ & $\begin{array}{l}0.015 \\
0.028\end{array}$ & $\begin{array}{l}0.012 \\
0.033\end{array}$ \\
\hline $\begin{array}{c}\text { Share of primary production } \\
\text { in GDP }\end{array}$ & $\begin{array}{l}-0.56^{* *} \\
0.28\end{array}$ & $\begin{array}{r}-0.17 \\
0.11\end{array}$ & $\begin{array}{r}-0.195 \\
0.187\end{array}$ & $\begin{array}{l}0.073 \\
0.077\end{array}$ & $\begin{array}{r}-0.08 \\
0.24\end{array}$ & $\begin{array}{r}-0.08 \\
0.21\end{array}$ \\
\hline $\begin{array}{c}\text { Sargan test } \\
\text { AR(2) test } \\
\text { Number of provinces } \\
\text { Number of observations }\end{array}$ & $\begin{array}{r}23.44 \\
-0.547 \\
25 \\
150\end{array}$ & $\begin{array}{r}20.10 \\
-1.60 \\
22 \\
85\end{array}$ & $\begin{array}{r}16.74 \\
-1.56 \\
20 \\
77\end{array}$ & $\begin{array}{r}17.31 \\
-0.74 \\
22 \\
85\end{array}$ & $\begin{array}{r}16.56 \\
-1.72 \\
20 \\
77\end{array}$ & $\begin{array}{r}18.51 \\
0.71 \\
20 \\
74\end{array}$ \\
\hline
\end{tabular}

Source: Authors' calculations.

GMM system estimator. 
Figure 1: Net Capital Inflows and Capital Productivity

(averaged over 1984-2001)

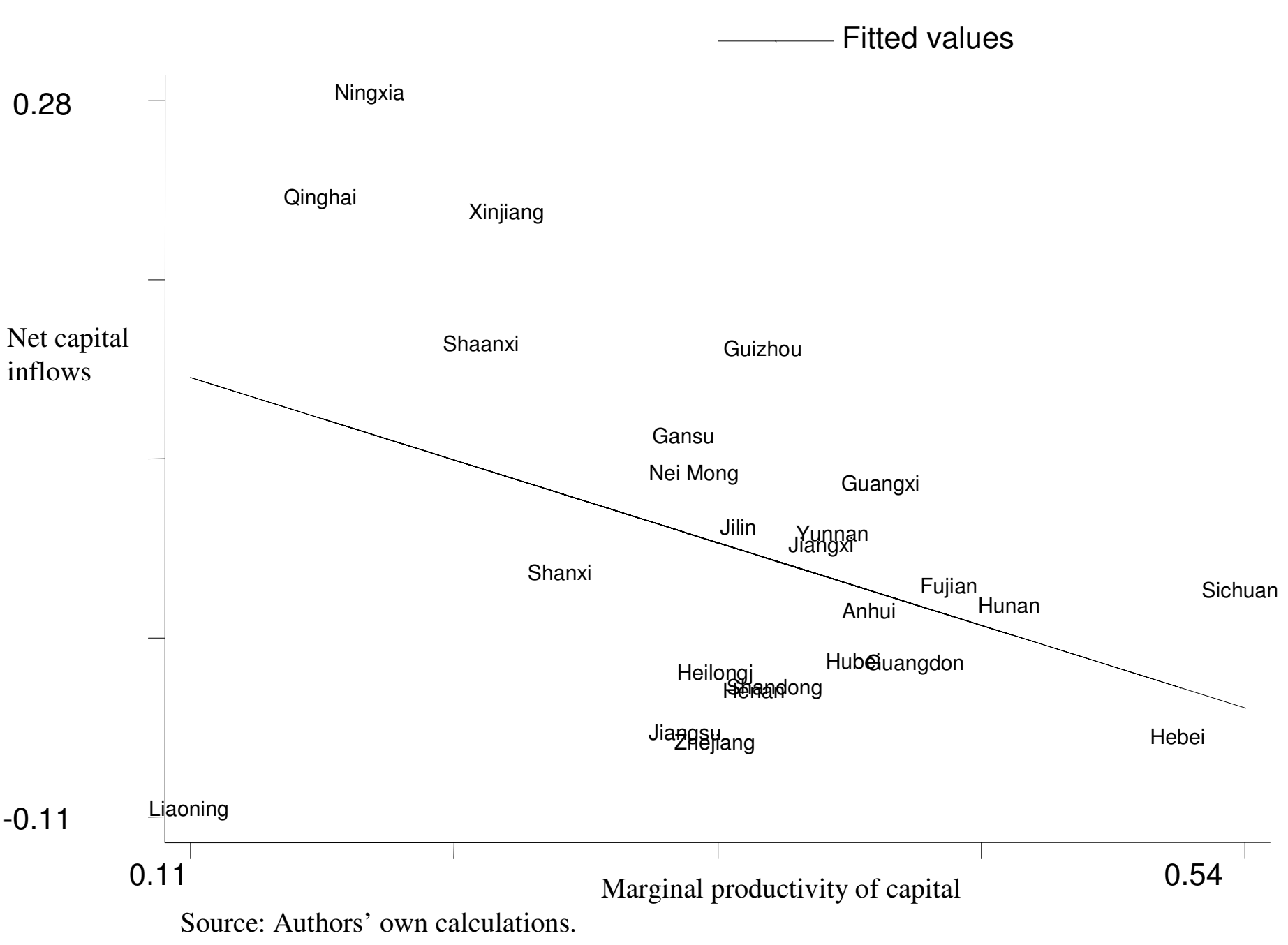




\section{References}

Allen, Franklin, Jun Qian, and Meijun Qian, forthcoming, "Law, Finance, and Economic Growth in China," forthcoming, Journal of Financial Economics.

Asdrubali, Pierfederico, Bent E. Sorensen, and Oved Yosha, 1996, "Channels of Interstate Risk Sharing: United States 1963-1990," Quarterly Journal of Economics, Vol. 111, No. 4, pp. 1081-110.

Atkeson, A and T. Bayoumi, 1993, "Do Private Capital Markets Insure Regional Risk? Evidence from the United States and Europe," Open Economies Review, Vol. 4, No. 3, pp. 303-24.

Atkinson, A. B., and Joseph E. Stiglitz, 1980, Lectures on Public Economics, London, McGraw Hill.

Bayoumi, Tamim A., and Andrew. K. Rose, 1993, "Domestic Savings and Intra-National Capital Flows," European Economic Review, Vol. 37, pp. 1197-202.

— Integration,” IMF Staff Papers, Vol. 42, No. 3, pp. 552-76.

— Papers, Vol. 44, No. 4, pp. 534-56.

Brainard, William C., and Richard N. Cooper, 1968, "Uncertainty and Diversification of International Trade," Food Research Institute Studies in Agriculture Economics, Trade, and Development, Vol. 8, pp. 257-85.

Coakley, Jerry, Kulai Farida and Ron Smith, 1998, "The Feldstein-Horioka Puzzle and Capital Mobility: A Review," International Journal of Finance and Economics, Vol. 3, pp. 169-88.

Crucini, Mario J., 1999, "On International and National Dimensions of Risk Sharing," Review of Economics and Statistics, Vol. 81, No. 1, pp. 73-84.

— and Gregory. D. Hess, 2000, "International and Intranational Risk Sharing," in Intranational Macroeconomics, ed. by Gregory D. Hess and Eric van Wincoop (Cambridge: Cambridge University Press).

Cull, Robert, and Lixin Colin. Xu, 2000, "Bureaucrats, State Banks, and the Efficiency of Credit Allocation: The Experience of Chinese State-Owned Enterprises," Journal of Comparative Economics, Vol. 28 (March), pp. 1-31.

— - M. Shen, and Lixin Colin. Xu, 2002, How Much is Lack of Finance Holding Back China's Interior Provinces? (Washington, D.C.: World Bank).

Dekle, Robert, 1996, "Saving-Investment Associations and Capital Mobility: On the Evidence from Japanese Data," Journal of International Economics, Vol. 41, pp. 53-72.

Du, Julan, and Shang-Jin Wei, 2004, “Does Insider Trading Raise Market Volatility?” Economic Journal, forthcoming.

Feldstein, Martin, and Charles Horioka, 1980, "Domestic Saving and International Capital Flows," The Economic Journal, Vol. 90, pp. 314-29. 
Frankel, Jeffrey A., 1992, "Measuring International Capital Mobility: A Review," American Economic Review, Papers and Proceedings, Vol. 82, pp. 197-202.

Greenwald, Bruce, and Joseph E. Stiglitz, 1986, "Externalities in Economies with Imperfect Information and Incomplete Markets," Quarterly Journal of Economics, 101: 229-264.

Hess, Gregory D., and Kwanho Shin, 1997, "International and Intranational Business Cycles," Oxford Review of Economic Policy, Vol. 13, No. 3, pp. 93-109.

Ho, Tsung-wu, 2002, "A Panel Cointegration Approach to the Investment Saving Correlation," Empirical Journal of Economics, Vol. 27, No. 1, pp. 91-100.

Huang, Ling, and Shang-Jin Wei, 2001, "One China, Many Kingdoms? Understanding Local Protection Using Individual Price Data," forthcoming, IMF Working Paper.

Imbs, Jean, and Romain Wacziarg, 2003, "Stages of Diversification," American Economic Review, Vol. 93, No. 1, pp. 63-86.

Iwamoto, Yasushi, and Eric van Wincoop, 2000, "Do Borders Matter? Evidence from Japanese Regional Net Capital Inflows,” International Economic Review, Vol. 41, No. 1, pp. 241-69.

Kalemi-Ozcan, Sebnem, Bent E. Sorensen, and Oved Yosha, 2001, "Risk Sharing and Industrial Specialization: Regional and International Evidence," unpublished.

Kemp, Murray, and Liviatan, Nissan, 1973, "Production and Trade Patterns under Uncertainty," The Economic Record, Vol. 49, pp. 215-27.

Lardy, Nicholas, 1998, China's Unfinished Economic Revolution (Washington DC: The Brookings Institution).

La Porta, Rafael, Florencio Lopez-de-Silanes, Andrei Shleifer, and Robert Vishny, 1997, "Legal determinants of external finance," Journal of Finance, 52: 1131-1150.

La Porta, Rafael, Florencio Lopez-de-Silanes, Andrei Shleifer, and Robert Vishny, 1998, "Law and Finance," Journal of Political Economy, 106: 1113-1155.

La Porta, Rafael, Florencio Lopez-de-Silanes, Andrei Shleifer, and Robert Vishny, 2002, "Government Ownership of Banks," Journal of Finance, 57(1): 256-301.

Li, Kui-Wai, 2003, "China’s Capital and Productivity Measurement Using Financial Resources," Economic Growth Center, Yale University, Center Discussion Paper 851 (February).

Naughton, Barry, 2000, “How Much Can Regional Integration Do to Unify China's Markets?" Center for Research on Economic Development and Policy Reform, Working Paper No. 58 (Aug).

Obstfeld, Maurice, 1994, “Are Industrial-Country Consumption Risks Globally Diversified?” in Capital Mobility: The Impact on Consumption, Investment, and Growth, ed. by Leonardo Leiderman and Assaf Razin (Cambridge: Cambridge University Press). 1995, "International Capital Mobility in the 1990s," in Understanding Interdependence: The Macroeconomics of the Open Economy, ed. by Peter B.Kenen (Princeton: Princeton University Press). 
Pakko, Mickael R., 1996, “Characterizing Cross-Country Consumption Correlations,” Review of Economics and Statistics, pp. 169-74.

Park, Albert, and Kaja Sehrt, 2001, "Tests of Financial Intermediation and Banking Reform in China," Journal of Comparative Economics, Vol. 29, No. 4 (December), pp. 608-44.

Parsley, David, and Shang-Jin Wei, 1996, "Convergence to the Law of One Price without Trade Barriers or Currency Fluctuation," Quarterly Journal of Economics, Vol. 111, 4:1211-36.

Poncet, Sandra, 2002, "Is China Disintegrating? The Magnitude of Chinese Provinces' Domestic and International Integration," CERDI Etudes et Documents, Vol. 5.

Qian, Yingyi, and Chenggang. Xu, 1993, "Why China's Economic Reform Differ: The M-Form Hierarchy and Entry/Expansion of the Non-State Sector," The Economics of Transition, Vol. 1, No. 2, pp. 135-70.

Rajan, Raghuram, and Luigi Zingales, 1998, "Financial Dependence and Growth,” American Economic Review, 88(3): 559-586.

Ruffin, Roy, 1974, “Comparative Advantage under Uncertainty,” Journal of International Economics, Vol. 4, No. 3 (August), pp. 261-73.

Sapienza, Paola, forthcoming, "The Effects of Government Ownership on Bank Lending," Journal of Financial Economics.

Shleifer, Andrei, 1998, "State versus Private Ownership,” Journal of Economic Perspectives.

Shleifer, Andrei, and Robert Vishny, 1998, The Grabbing Hand: Government Pathologies and Their Cures, Harvard University Press, Cambridge, MA.

Sinn, Stefan, 1992, "Saving-Investment Correlations and Capital Mobility: On the Evidence from Annual Data," The Economic Journal, Vol. 102, pp. 1062-170.

Stiglitz, Joseph E., and Andrew Weiss, 1981, "Credit Rationing in Markets with Imperfect Information," American Economic Review, 71: 393-410.

Tan, Kong-Yam, and Zhang Xiaobo, 2003, "Factor Market Integration Across Sectors and Regions: Implications for Economic Growth in China," paper presented at the World Bank Workshop on National Market Integration, Beijing, September 6.

Thomas, Alun H., 1993, "Saving, Investment, and the Regional Current Account: An Analysis of Canadian, British, and German Regions," IMF Working Paper 93/62.

van Wincoop, Eric, 1995, "Regional Risk Sharing," European Economic Review, Vol. 37, p1545-67.

World Bank, 1994, China: Internal Market Development and Regulation, World Bank Country Study (Washington, D.C.: World Bank).

Xie, Duo, 2002, “Analysis of the Development of China's Money Market," China \& World Economy, 1: 29-37. 
Yamori, Nobuyoshi, 1995, "The Relationship between Domestic Savings and Investment: the Feldstein-Horioka Test using Japanese Regional Data,” Economic Letters, 48: 361-66.

Yi, Gang, 2003, "Changes in China Capital Market," Workshop on National Market Integration, World Bank and Development Research Center of the State Council, September.

Young, Alwyn, 2001, "The Razor's Edge: Distortion and Incremental Reform in the People's Republic of China," Quarterly Journal of Economics, Vol. 115 No. 4, pp. 1091-1135. 